Estimating GSP and Labor Productivity by State

by Paul W. Bauer and Yoonsoo Lee 


\section{Estimating GSP and Labor Productivity by State}

by Paul W. Bauer and Yoonsoo Lee

In gauging the health of state economies, arguably the two most important series to track are employment and output. While employment by state is available about three weeks after the end of a month, data on output, as measured by Gross State Product (GSP), are only available annually and with a significant lag. This Policy Discussion Paper details how more current estimates of GSP can be generated using U.S. Gross Domestic Product and personal income along with individual states' personal income. A straightforward share approach yields reasonable GSP estimates, but a more sophisticated econometric approach, at a cost of imposing more structure, yields even better ones. Both techniques are also applied to estimate nonfarm-business GSP in order to calculate a measure of labor productivity at the state level that follows as closely as possible the method used by the Bureau of Labor Statistics to calculate the national measure of labor productivity. We then briefly examine how labor productivity varies across states.
POLICY DISCUSSION PAPERS

Policy Discussion Papers are published by the Research Department of the Federal Reserve

Bank of Cleveland. To receive copies or to be placed on the mailing list, e-mail your request

to 4d.subscriptions@clev.frb.org or fax it to 216.579.3050.

Policy Discussion Papers are available electronically through the Cleveland Fed's site on the World Wide Web: www.clevelandfed.org/Research.

Views stated in Policy Discussion Papers are those of the authors and not necessarily those of the Federal Reserve Bank of Cleveland or of the Board of Governors of the Federal Reserve System.
Paul W. Bauer is an economic advisor at the Federal Reserve Bank of Cleveland. Yoonsoo Lee is an economist at the Bank.

Materials may be reprinted if the source is credited. Please send copies of reprinted materials to the editor.

We invite questions, comments, and suggestions. E-mail us at editor@clev.frb.org. 


\section{Introduction}

Data on the Gross State Product (GSP), the state counterpart of the U.S. Gross Domestic Product (GDP), for 2001 were released in May of 2003. Data for 2002 and a "prototype" estimate for 2003 were released in December of 2004. Important data required for policymakers? Definitely. But if this data were more timely, even with some error, they could be even more useful.

In gauging the health of the regional economy, arguably the two most important series to track are employment and output. Both series are of interest in themselves, but combined they form a measure of productivity that in the long run ultimately drives living standards. While employment by state is available approximately three weeks after the end of a given month, data on output - as measured by the Bureau of Economic Analysis' (BEA) GSP — are only available annually and with a multi-year lag. Yet GSP is just as important an indicator of state economic performance as GDP is of national. GSP is the broadest measure of a state's production of goods and services, and looking at GSP over time can help identify regional business cycles. Following GSP can also aid states in managing their finances, as a significant proportion of state tax revenue is tied to output rather than to employment. Of course, the more timely GSP data are, the more useful they become.

This Policy Discussion Paper details how more current estimates of GSP can be generated using U.S. GDP and personal income combined with individual states' personal income. Two approaches are discussed and compared to actual GSP to determine how well they perform. A simple model that requires no parametric regression estimates provides fairly good GSP estimates for most states; however, a regression model performs even better, particularly for states that have a large share of GSP coming from natural resources, such as oil.

We also use these approaches to estimate nonfarm-business GSP. This series is useful for calculating estimates of labor productivity for states that follow as closely as possible the method used in calculating the most widely watched national measure. Explaining the variation in productivity growth across states has been an important topic among economists; for example, Beeson (1987), Beeson and Husted (1989), and Hulten and Schwab (1984) look at productivity and efficiency of manufacturing across states. Measuring labor productivity is important to economists and policymakers because, in the long run, labor-productivity growth is closely tied to gains in wages and living standards. At the state level, laborproductivity growth provides a measure of a state's competitive position over time.

In constructing a measure of state-level productivity, we follow as closely as possible the method used by the Bureau of Labor Statistics to calculate output-per-worker-hour for the private nonfarmbusiness economy, perhaps the most watched measure of productivity at the national level. One unavoidable problem is that, at the national level, nonfarm-business labor productivity is calculated in terms of output per hour, but at the state level, only data on the number of workers are available. Consequently, we are forced to look at output per worker. In order to better understand the properties of this productivity measure, we compare output per hour and output per worker using data at the national level where both can be calculated to show how these two measures differ over the long run and over the business cycle. We then briefly examine how labor productivity varies across states. 


\section{Estimation Techniques}

In this section we describe two techniques for estimating a given state's GSP. One approach, first used by the Federal Reserve Bank of San Francisco, involves no econometric estimation and can be obtained as follows:

(1) $G S P_{i t}=G D P_{t}^{*} P I_{i t} / P I_{t}$,

where $G S P_{i t}$ is the estimate of GSP for state $i$ in period $t, G D P_{t}$ is U.S. GDP in period $t, P I_{i t}$ is the personal income of state $i$ in period $t$, and $P I_{t}$ is U.S. personal income in period $t$. This approach assumes that personal income's share of output is roughly constant over time and similar across all states. As we will see in the next section, this approach does a fairly good job for most states and has the advantage of having no econometric parameters that have to be re-estimated as time goes by. Unfortunately, we will also see that the assumption that personal income's share of output is constant across states does not hold very well, particularly for natural-resource-rich states.

Our other approach uses these same series but employs an econometric model with lags to develop a potentially better fit. We estimate the following equation for each state and the District of Columbia:

(2) $\Delta \ln G S P_{i t}=\alpha_{i}+\beta_{1 i} \ln G D P_{t}+\beta_{2 i} \ln G D P_{t-1}$

$$
+\eta_{1 i} \ln P I_{i t}+\eta_{2 i} \ln P I_{i, t-1}+\lambda_{1 i} \operatorname{In} P I_{t}+\lambda_{2 i} \ln P I_{t-1}+\varepsilon_{i t} \text {. }
$$

We use the growth rate of a state's GSP as the dependent variable because we want to fit growth rates as well as possible. Toward that end we also include lagged values of personal income and GDP.

Assuming that these parameter estimates are relatively stable over a one- to two-year horizon going forward, we can obtain estimates of a state's GSP for time periods in which the BEA has not yet released the official GSP figures, but for which GDP and personal income are available. In addition to comparing how well these techniques perform in sample, we also calculate GSP estimates for 2003 and 2004. But first it is useful to briefly review the definition and characteristics of the data we will be using.

\section{Data}

In both estimation techniques, we use the annual estimates of nominal GDP published by the BEA as the measure of national output. GDP measures total value of all goods and services produced by labor and property located in the United States.

As defined by the BEA, GSP is a value-added concept that is consistent with the nation's GDP. ${ }^{1}$ For a given state, overall GSP is the sum of the GSP originating in all industries in the state. Specifically, an industry's GSP is equal to its gross output (defined as sales or receipts and other operating income, commodity taxes, and inventory change) minus its intermediate inputs (consumption of goods and services purchased).

Although GSP is related to GDP, the sum of states' GSP for a given year is not precisely equal to U.S. GDP for several reasons. First, GSP is measured as the sum of the distributions by industry of the components of gross domestic income, which differs from GDP by the statistical discrepancy; insufficient information is available to allocate the statistical discrepancy across states. Second, unlike GDP, GSP does not include the compensation and other expenses related to federal civilian and

1. For full details see, Bureau of Economic Analysis, "State Personal Income Methodology, 1998-2003," http://www.bea.gov/bea/ regional/articles/spi2003/. 
military personnel stationed abroad. Lastly, the sum of states' GSP and GDP can differ because they have different revision schedules.

In addition to GSP, the BEA also publishes personal income for the U.S. and for individual states. State personal income, published quarterly, is loosely defined as the income received by all the residents of the state from all sources. Personal income includes the sum of wages and salaries, proprietors' income, personal dividend, and interest income. Here, persons consist of nonprofit institutions that serve individuals, private non-insured welfare funds, private trust funds, and individuals. The state-level estimates of personal income are designed to be conceptually and statistically consistent with the national estimates of personal income. ${ }^{2}$

Our main goal is to obtain more current estimates of GSP, so we want to extend the data as far forward as can reasonably be done. ${ }^{3}$ When we collected the data for this paper, data for U.S. personal income and GDP were available through 2004 (in contrast to GSP data, which were only available for the years 1977-2002, although a "prototype" estimate for 2003 was first released in December 2004).

\section{How Well Do These Approaches Perform?}

Econometric results from equation 2 for each state are presented in table 1. For all but a handful of states, the R-square is fairly high, with a median of 0.831 . This suggests that the model fits the data fairly well, but does it outperform equation 1, the personal-income-share approach? One way to compare the performance of these two techniques is to look at the mean absolute percentage deviations for each technique from the actual published data (see table 2$).{ }^{4}$ For every state except Tennessee, equation 2's estimates (the regression approach) outperformed equation 1's (the personal-income-share approach), so it is not surprising that both the mean and the median of the absolute percentage deviations are lower for the estimates from the regression approach than for those from the personalincome-share approach. The means for equation 1 and 2 are 0.0732 and 0.0140 , while the medians are 0.0449 and 0.0109 , respectively.

A closer look at these figures reveals that for most states, both techniques work fairly well; yet for states that have a large share of their GSP coming from mining (such as Alaska, Texas, Louisiana, and West Virginia), the regression approach (equation 2) performs far better than the personal-incomeshare approach (equation 1). This latter approach also appears to have trouble forecasting the GSP level for small states and the District of Columbia. For example, the mean absolute percentage deviation of heavily oil-dependant Alaska is 0.3242 for equation 1, yet only 0.0565 for equation 2 .

Sometimes economic observers are more interested in growth rates than levels. This is a more challenging test because to get a good estimate of a growth rate, implicity one needs to obtain good estimates of two levels. The results of looking at mean absolute deviations in growth rates are presented in table 3 . Here, although the regression approach still outperforms the personal-income-share approach for every state but Washington, the advantage of the regression approach is much smaller. The means are 0.0156 and 0.0130 , while the medians are 0.0114 and 0.0103 , respectively.

A few figures can graphically illustrate the findings above. For some large diversified states such as California, New York, and even Kentucky, it is visually hard to discern much of a difference. Although

2. See BEA, "State Personal Income Methodology, 1997-2002" for details about the estimates and differences between state and national estimates.

3. For researchers interested in past economic performance, our techniques could also be applied to obtain GSP estimates prior to 1977. Although annual estimates of personal income extend back to 1929, it would not be reasonable to extend the estimates that far back because the parameter estimates are unlikely to be stable over very long periods of time. As we will see, the parameter estimates of state-level-GSP regression show large variation across states that seems to originate from differences in industry composition across states. In particular, these differences are most noticeable among states with a relatively large share of industries that have low shares of labor shares or volatile output over time, such as mining. Given that the U.S. economy has experienced significant restructuring across industries since 1929, while our estimates could reasonably be used to extend the GSP series back a few years, we certainly do not believe the parameter estimates obtained for the period from 1977 to 2001 should be employed to estimate the GSP back to 1929 .

4. While the personal-income-share approach directly estimates GSP levels, the regression approach estimates percentage growth rates of GSP. GSP levels are calculated from the BEA estimates of 1977 GSP and estimated growth rates from the regression approach. 
both approaches work well for fitting the level of GSP for certain states, the regression approach outperforms the personal-income-share approach for Ohio and Pennsylvania (see figure 1a-e). Similarly, for changes in GSP, it is easy to see that the fit is not quite as good when looking at growth rates (figure $2 \mathrm{a}-\mathrm{e}$ ).

For states such as Alaska, Texas, Louisiana, and West Virginia (see figure 3a-d for levels and figure $4 \mathrm{a}-\mathrm{d}$ for growth rates) that have a significant share of GSP coming from mining, the personalincome-share approach clearly does not perform as well as the regression approach, visually confirming the results reported in table 2 .

In summary, the regression approach (equation 1) fits the data better than the personal-incomeshare approach (equation 2). For most states, the actual and estimated levels and growth rates are very close using the latter approach. While we do not have enough observations to perform meaningful out-of-sample analysis of these two approaches, it appears that useful, more-timely estimates of GSP can be obtained for most states. We now demonstrate how estimates of state-level labor-productivity estimates can be obtained.

\section{Constructing State Labor-Productivity Indices}

To construct a measure of state productivity comparable to the most widely watched national productivity measure (output per hour for nonfarm business), an estimate of nonfarm business GSP is needed in addition to the more-timely estimates of overall GSP. To obtain this measure of state output, we follow the major sectors and subsectors of the U.S. economy included in the Bureau of Labor Statistics (BLS) measure for nonfarm business. Due to the differences in classification of sectors, some components of the data used in the BLS measures are not available at the state level. ${ }^{5}$ Real GSP in the nonfarmbusiness sector is constructed from the private-industry GSP from the BEA, excluding the outputs of private households and agricultural sectors (Agriculture Services, forestry and fishing as well as farms). ${ }^{6}$ For the years we are forced to estimate GSP, we estimate nonfarm-business GSP using equation 2, but instead of using all state personal income, we use state personal income in the nonfarm-business sector only. We then divide these GSP estimates by the BEA's GDP deflator to obtain real output estimates. ${ }^{7}$

For the denominator of our labor-productivity index, a measure of the quantity of labor inputs is required. At the national level, the BLS publishes series for both the number of workers and the hours worked, but unfortunately data on the number of hours are not available by state. As an alternative, we use the number of workers as our labor input measures. The BLS Current Employment Statistics program provides employment in non-agricultural establishments for states. Since the payroll employment does not include employees of private households, we just have to exclude government employment to get nonfarm-business-industry employment.

This difference in the measures calls for caution when comparing the state labor-productivity measures to the national labor-productivity measures. If all employees worked a standard 40-hour work week, then the two series would contain identical information, but this is not the case. Salaried workers, part timers, overtime workers, and workers with multiple jobs all loosen the link between hours and number of workers.
5. See Beemiller and Downey (2001) for more details on GSP estimates by industry.

6. The BEA has not published GSP for private households since 1998 , when it switched from SIC to NAICS. Our nonfarm private GSP measures for years after 1998 thus include private households, which account for only less than 1 percent of total GSP.

7. Real business-sector output in the BLS measures excludes the following outputs from the gross domestic product: general government, nonprofit institutions paid employees of private households, and the rental value of owner-occupied dwellings. The rental value of owner-occupied dwellings is not available at the state level and thus not subtracted from the output. 
At the national level, where both measures of labor input are available, we can explore the differences in the labor-productivity measures based on hours and those based on workers. In figure 5a, we plot the standard measure of nonfarm private business-labor productivity (output per hour) with an alternative measure (output per worker). While the two series are clearly similar, they do differ in two significant ways. The most obvious way is how they move over the business cycle. In a downturn, employers tend to retain workers but reduce hours, thus lowering output per worker relative to output per hour. In a recovery, employers tend to be cautious in hiring as demand rebounds, and they tend to increase workers' hours more quickly than the number of workers, thus raising output per worker relative to output per hour. This phenomenon is clearly seen in the last peak as output per worker plunged in 2000 and 2001 only to sharply rebound in subsequent years. The other way the two measures of labor productivity differ is that there is a long-run trend toward fewer hours per worker, mainly because of the growth in the number of part-time workers. This phenomenon is only subtly manifest in figure 5 a by the growth rate in output per worker tending to be below that of output per hour; it is more clearly seen in figure $5 \mathrm{~b}$, which directly plots hours per worker.

The bottom line is that when making longer-term comparisons, the two series will tend to yield similar results, especially if one adjusts for the trend toward fewer hours per worker. However, when considering year-to-year movements in productivity, this differing behavior over the business cycle must be kept in mind.

In comparing the state-level measures to the national labor-productivity measures, it is also important to remember that the definition of GSP is not the same as GDP. Figure 5c shows, at the national level, the relationship between the GDP per worker and GSP (nonfarm business summed over all of the states) per worker. Note that in the national comparisons, using GSP rather than GDP makes about the same amount of difference in the productivity figures as does using the number of workers rather than the number of hours.

\section{A First Look at Labor Productivity across States}

In figure 6a, we plot each state's average annual labor-productivity growth rate from 1977 to 2000. The first thing to notice is how remarkably wide the variation is across states. States averaged 1.1 percent growth over this period, from a low of -0.4 percent in Alaska to Connecticut's comparatively blistering 2.8 percent. In the Fourth District, Pennsylvania led with 1.3 percent, followed by Ohio (0.8 percent), Kentucky (0.4 percent), and West Virginia ( -0.3 percent).

During the period since the last business-cycle peak (2000-04), states' average annual labor productivity grew 2.3 percent — an increase of 1.2 percentage points over the previous period-but again this gain was far from evenly distributed (see figure 6b). This is not entirely surprising, considering the differential impact of the economic downturn on the states and their industries during these years. Delaware led the nation with average annual labor-productivity growth that soared to 8.6 percent; eight states experienced declines, led by Alaska at -4.5 percent.

In the Fourth District, state labor-productivity growth exceeded that of the nation from 2000 to 2004. In particular, West Virginia rose from the second-slowest-growing state from 1977 to 2000 to the sixth-fastest-growing, at 4.4 percent. Kentucky, at 2.4 percent, went from sixth-slowest to midpack 
performer. Ohio and Pennsylvania, at 3.7 percent and 3.2 percent respectively, also turned in solid numbers. Given that the current expansion has not been kind to the Fourth District, particularly Ohio, the region's strong relative labor-productivity growth comes as a bit of a surprise.

In figure $7 \mathrm{a}$ we plot the level of labor productivity for selected large states along with the national average of GSP per worker. The level of labor productivity for California and New York remain well above the national average over the whole period. Texas, buoyed by high real prices for petroleum products, performed as well or better in the late 1970s to mid-1980s but has since fallen off toward the national average. Florida's labor productivity, despite its rapid growth in GSP over this period, remains well below the national average. Figure $7 \mathrm{~b}$ plots the growth rate of labor productivity for this group. The growth rates are quite volatile at the state level. The oil-price collapse in 1986 is clearly visible in Texas's series, as is the dot-com boom and bust around 2000 in California's.

Figure 8a plots the Fourth District states' levels of labor productivity along with the nation's. Note that all of the states trail the nation over this period. High real prices for coal helped Kentucky and West Virginia in the late 1970s but hurt them as its real price fell later. First Kentucky and then West Virginia have managed to boost their labor productivity. Ohio and Pennsylvania have largely moved together, although they have swapped places: in the late 1970s, Ohio's labor productivity was closer to the nation's, but in 1990, Pennsylvania's was closer. Looking at the growth rates in figure 8b, a great deal of volatility is again seen, particularly for Kentucky and West Virginia around 2000. Coal prices did slump for 1998 through 2000, but further investigation is required to explore what else may have contributed to the extremely sharp decline in those states' labor-productivity growth rates. Since 2002, all the Fourth District states have outperformed the nation, particularly Ohio.

\section{Summary}

Two approaches to speeding up the availability of GSP data are discussed and compared to actual GSP to determine how well each approach performs. The first model requires no estimation and provides fair estimates for most states. However, our regression model performs much better, particularly for states that have a large share of GSP coming from mining.

We also construct estimates of private nonfarm-labor productivity for states in as similar a way as possible to the way U.S. estimates are constructed. After discussing how the state measure differs conceptually from the national one, we provide a brief look at how labor productivity has varied across states, focusing on large states and Fourth District states. Perhaps the most interesting finding is how much variation there is across states; looking for the sources of this variation is an important project left to future research. 


\section{References}

Richard M. Beemiller and George K. Downey. 2001. “Gross State Product by Industry, 1992-99,” Survey of Current Business, vol. 81 (August): 159-72.

Patricia Beeson. 1987. "Total Factor Productivity Growth and Agglomeration Economies in Manufacturing, 1959-73," Journal of Regional Science, vol. 27, no. 2.

Patricia E. Beeson and Steven Husted. 1989. "Patterns and Determinants of Productive Efficiency in State Manufacturing,” Journal of Regional Science, vol. 29, no. 1:15-28.

Bureau of Economic Analysis, "State Personal Income Methodology, 1998-2003," http://www.bea.gov/bea/regional/articles/spi2003/.

Charles R. Hulten and Robert M. Schwab. 1984. "Regional Productivity Growth in U.S. Manufacturing: 1951-1978," American Economic Review, vol. 71, no. 1 (March): 152-62. 
Table 1: Regression Approach Estimates

\begin{tabular}{|c|c|c|c|c|c|c|c|c|c|c|c|c|c|}
\hline \multirow{2}{*}{\begin{tabular}{|l|} 
State \\
Alabama
\end{tabular}} & \multicolumn{2}{|l|}{ Inpi } & \multicolumn{2}{|l|}{ |linpi_lag } & \multicolumn{2}{|c|}{ |nus_pi } & \multicolumn{2}{|c|}{ |lnus_pi_lag } & \multicolumn{2}{|c|}{ ||nus gdp } & Inus_gdp lag & \multirow{2}{*}{$\mid$\begin{tabular}{||c||} 
Constant \\
$0.735[2.000]$
\end{tabular}} & \multirow{2}{*}{\begin{tabular}{||c|} 
R-squared \\
0.821
\end{tabular}} \\
\hline & \multirow{2}{*}{\multicolumn{2}{|c|}{$\begin{array}{l}0.643[0.368] \\
0.633[0.881]\end{array}$}} & \multicolumn{2}{|c|}{$-0.525[0.345]$} & $-0.798^{*}$ & {$[0.302]$} & $0.671^{*}$ & {$[0.281]$} & $0.930^{* *}$ & {$[0.303]$} & $\mid \begin{array}{ll}-0.931^{*} \quad[0.352] \\
\end{array}$ & & \\
\hline Alaska & & & $-1.497^{*}$ & [0.698] & \multicolumn{2}{|c|}{ |-1.797[2.984] } & \multicolumn{2}{|c|}{$0.87[2.886]$} & \multicolumn{2}{|c|}{4.066 [2.674] } & $-2.366[2.882]$ & 8.199 [21.068] & 0.518 \\
\hline Arizona & $1.099^{* *}$ & {$[0.277]$} & $-1.311^{* *}$ & [0.225] & & {$[0.398]$} & & $+[0.418]$ & & {$[0.412]$} & $-0.432[0.398]$ & $-1.647[3.094]$ & 0.846 \\
\hline Arkansas & $0.924^{* *}$ & {$[0.192]$} & $-1.005^{* *}$ & {$[0.192]$} & $-0.983^{*}$ & {$[0.273]$} & $0.683^{*}$ & {$[0.247]$} & $0.863^{* k}$ & [0.294] & $-0.484[0.325]$ & $2.19[1.723]$ & 0.870 \\
\hline California & $1.268^{* *}$ & [0.430] & $-1.361^{* *}$ & [0.430] & & {$[0.738]$} & & $1[0.704]$ & & [0.405] & $-0.746[0.467]$ & $-2.885[3.084]$ & 0.788 \\
\hline Colorado & $0.914^{* *}$ & {$[0.147]$} & $-0.897^{* *}$ & {$[0.152]$} & & {$[0.365]$} & & $4[0.373]$ & $0.651^{*}$ & [0.259] & $-0.125[0.329]$ & 3.313 [2.052] & 0.901 \\
\hline Connecticut & $0.811^{* *}$ & [0.259] & $-0.915^{* *}$ & [0.266] & & {$[0.561]$} & & [0.489] & & [0.352] & $-0.533[0.387]$ & $0.128[2.434]$ & 0.816 \\
\hline Delaware & & $2[0.466]$ & -0.8 & {$[0.452]$} & & {$[0.749]$} & & $8[0.644]$ & & [0.586] & $-0.266[0.628]$ & $-2.3[3.657]$ & 0.410 \\
\hline District of Columbia & $0.614^{* *}$ & {$[0.199]$} & $-0.640^{*}$ & [0.228] & & {$[0.598]$} & & $7[0.359]$ & & [0.413] & $-0.729[0.384]$ & $1.145[3.265]$ & 0.687 \\
\hline Florida & 0.1 & $6[0.176]$ & $-0.390^{*}$ & [0.162] & & {$[0.242]$} & & $8[0.226]$ & $0.532^{* *}$ & {$[0.166]$} & {$\left[\begin{array}{ll}-0.748^{* *} & {[0.195]}\end{array}\right.$} & $-2.346[1.264]$ & 0.947 \\
\hline Georgia & $1.625^{* *}$ & {$[0.261]$} & $-1.744^{* *}$ & [0.284] & $-1.513^{*}$ & {$[0.330]$} & $1.275^{* *}$ & {$[0.268]$} & $0.836^{* *}$ & {$[0.254]$} & $-0.44[0.286]$ & $1.373[1.544]$ & 0.900 \\
\hline Hawaii & $0.903^{* *}$ & {$[0.130]$} & $-1.014^{* *}$ & [0.128] & $-0.789^{*}$ & [0.311] & $0.736^{*}$ & [0.273] & & {$[0.274]$} & $-0.294[0.333]$ & $0.92[1.916]$ & 0.900 \\
\hline Idaho & $1.102^{* *}$ & {$[0.176]$} & $-1.151^{* *}$ & {$[0.176]$} & $-1.682^{*}$ & [0.369] & $1.291^{* *}$ & [0.347] & $1.562^{* *}$ & [0.346] & 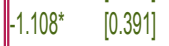 & 2.46 [2.273] & 0.830 \\
\hline Hllinois & $1.208^{* *}$ & [0.286] & $-1.217^{* *}$ & [0.224] & $\mid-1.212^{*}$ & [0.357] & $1.271^{* *}$ & [0.343] & $1.004^{* *}$ & {$[0.176]$} & $\begin{array}{lll}-1.055^{* \star} & {[0.225]}\end{array}$ & $-0.325[1.297]$ & 0.900 \\
\hline Indiana & $1.548^{* *}$ & [0.330] & $-1.613^{* *}$ & [0.263] & $-0.960^{*}$ & {$[0.306]$} & $1.323^{* *}$ & [0.359] & & [0.333] & $-0.982^{* *}$ & $-2.251[2.145]$ & 0.871 \\
\hline lowa & $0.504^{* *}$ & {$[0.128]$} & $-0.837^{* *}$ & [0.114] & $-0.713^{*}$ & [0.264] & & [0.245] & $1.515^{* *}$ & [0.238] & $-0.622^{*}$ & $4.940^{* *} \quad[1.546]$ & 0.923 \\
\hline Kansas & $1.004^{* *}$ & {$[0.142]$} & $-1.026^{* *}$ & {$[0.137]$} & $-0.938 *$ & [0.241] & $0.684^{* *}$ & {$[0.232]$} & $0.993^{* *}$ & {$[0.157]$} & $-0.706^{* *} \quad[0.189]$ & $1.592[1.361]$ & 0.947 \\
\hline Kentucky & 0.5 & $7[0.355]$ & -0.7 & {$[0.357]$} & & {$[0.536]$} & & $1[0.540]$ & $1.290^{* *}$ & [0.432] & $-0.932[0.498]$ & 2.012 [2.935] & 0.600 \\
\hline Louisiana & $1.287^{* *}$ & [0.381] & $-1.168^{* *}$ & {$[0.368]$} & & {$[1.069]$} & & [1.062] & & {$[0.906]$} & $0.041[1.106]$ & $10.097[6.826]$ & 0.689 \\
\hline Maine & $1.115^{* *}$ & {$[0.171]$} & $-1.184^{* *}$ & {$[0.166]$} & $-0.706^{*}$ & [0.292] & $0.873^{* *}$ & [0.253] & $0.526^{*}$ & {$[0.224]$} & $-0.632^{*} \quad[0.265]$ & $-0.915[1.571]$ & 0.892 \\
\hline Maryland & $1.329^{* *}$ & {$[0.203]$} & $-1.428^{* *}$ & {$[0.196]$} & $\mid-1.473^{*}$ & [0.290] & $1.455^{* *}$ & [0.211] & $1.108^{* *}$ & {$[0.179]$} & $-0.994^{* *}$ & 0.357 [1.352] & 0.927 \\
\hline Massachusetts & $1.339^{* *}$ & {$[0.096]$} & $-1.415^{* *}$ & {$[0.095]$} & $-1.536^{*}$ & {$[0.210]$} & $1.376^{* *}$ & {$[0.168]$} & $1.153^{* *}$ & {$[0.138]$} & $-0.915^{* *}$ & $1.278[1.015]$ & 0.974 \\
\hline Michigan & $1.194^{*}$ & [0.484] & $-1.215^{* *}$ & {$[0.366]$} & & [0.480] & $1.602^{*}$ & [0.599] & \begin{tabular}{|l}
0.9 \\
0.9
\end{tabular} & [0.617] & $-1.869^{*}$ & $-6.095[5.069]$ & 0.705 \\
\hline Minnesota & $1.006^{* *}$ & [0.263] & $-0.953^{* *}$ & [0.232] & $-0.852^{*}$ & [0.383] & $0.774^{*}$ & [0.357] & $1.049^{* k}$ & [0.229] & $-1.013^{* *}$ & $0.184[1.654]$ & 0.880 \\
\hline Mississippi & $0.973^{* *}$ & {$[0.196]$} & $-0.941^{* *}$ & {$[0.196]$} & $-1.015^{x}$ & {$[0.255]$} & $0.817^{* *}$ & [0.257] & $0.896^{* *}$ & [0.253] & {$\left[\begin{array}{ll}-0.736^{*} & {[0.270]}\end{array}\right.$} & $1.393[1.637]$ & 0.878 \\
\hline Missouri & $1.412^{* \star}$ & {$[0.437]$} & -0.7 & $3[0.432]$ & $\mid-0.944^{*}$ & [0.399] & & $4[0.388]$ & & [0.355] & $-0.573[0.398]$ & $0.938[2.128]$ & 0.744 \\
\hline Montana & $0.895^{* *}$ & {$[0.145]$} & $-0.809^{* *}$ & [0.149] & $-1.038^{*}$ & {$[0.405]$} & & $3[0.385]$ & $1.306^{* x}$ & [0.355] & $-0.52[0.426]$ & 4.745 [2.511] & 0.821 \\
\hline Nebraska & $0.602^{* *}$ & {$[0.165]$} & $-1.039^{* *}$ & {$[0.164]$} & & {$[0.345]$} & & $6[0.310]$ & $1.257^{\star *}$ & {$[0.296]$} & {$\left[\begin{array}{ll}-0.886^{*} & {[0.344]}\end{array}\right]$} & $0.605[2.039]$ & 0.865 \\
\hline Nevada & $0.665^{* *}$ & {$[0.119]$} & $-0.707^{* *}$ & [0.112] & $-0.929 *$ & [0.155] & & $1[0.237]$ & $1.201 * *$ & [0.161] & {$\left[\begin{array}{ll}-0.644^{* *} & {[0.205]}\end{array}\right.$} & $2.923[1.492]$ & 0.964 \\
\hline New Hampshire & $0.992^{* *}$ & [0.216] & $-1.046^{* *}$ & [0.206] & $-1.469^{*}$ & [0.494] & $1.329^{* *}$ & {$[0.454]$} & $1.018^{*}$ & [0.401] & $-0.835[0.472]$ & 1.224 [2.947] & 0.822 \\
\hline New Jersey & $0.932^{* *}$ & {$[0.243]$} & $-1.048^{* *}$ & {$[0.254]$} & $-1.121^{*}$ & [0.433] & $1.649^{* *}$ & [0.381] & $0.865^{* *}$ & [0.251] & $\left.\begin{array}{ll}-1.304^{* *} & {[0.268}\end{array}\right]$ & $-2.702[1.696]$ & 0.874 \\
\hline New Mexico & 1.03 & $4[0.552]$ & $-1.312^{*}$ & [0.532] & & [1.011] & & [0.987] & $\mid \begin{array}{l}\mid \\
1.8\end{array}$ & [0.890] & $-0.568[1.037]$ & $6.346[6.238]$ & 0.498 \\
\hline New York & $0.972^{* *}$ & {$[0.233]$} & $-1.093^{* *}$ & [0.243] & $-0.891^{*}$ & [0.410] & $1.071^{k *}$ & {$[0.334]$} & $0.772^{* *}$ & [0.254] & $\mid-0.850^{* *} \quad[0.263]$ & $-0.403[1.639]$ & 0.881 \\
\hline North Carolina & $0.897^{\star \star}$ & {$[0.313]$} & -0.5 & {$[0.400]$} & & {$[0.384]$} & $0.836^{*}$ & {$[0.312]$} & & [0.296] & $-1.407^{\star \star}$ & $-2.846[1.842]$ & 0.823 \\
\hline North Dakota & $0.561^{* *}$ & [0.139] & $-0.853^{* *}$ & [0.131] & & {$[0.752]$} & & [0.760] & & [0.691] & $0[0.879]$ & $7.107[4.958]$ & 0.826 \\
\hline Ohio & $1.781^{* \star}$ & [0.445] & $-1.165^{*}$ & [0.422] & $-1.053^{*}$ & {$[0.327]$} & $1.223^{* *}$ & {$[0.340]$} & & [0.307] & $\begin{array}{ll}-1.306^{* *} & {[0.370]}\end{array}$ & $-4.766[2.464]$ & 0.847 \\
\hline Oklahoma & $1.372^{* *}$ & {$[0.230]$} & $-1.360^{* *}$ & [0.223] & & {$[0.776]$} & & $5[0.800]$ & & [0.584] & $-0.316[0.745]$ & 5.201 [5.129] & 0.844 \\
\hline Oregon & $0.883^{*}$ & {$[0.349]$} & $-1.030^{* *}$ & {$[0.321]$} & $-1.004^{*}$ & {$[0.460]$} & & $6[0.580]$ & $1.219^{*}$ & [0.480] & $-0.552[0.519]$ & $3.09[3.713]$ & 0.742 \\
\hline Pennsylvania & 0.16 & $7[0.395]$ & -0.3 & {$[0.370]$} & & {$[0.380]$} & & [0.396] & $0.901 * *$ & [0.226] & $\left.\begin{array}{ll}-0.810^{*} & {[0.289}\end{array}\right]$ & $0.6[1.663]$ & 0.771 \\
\hline Rhode Island & $0.912^{* *}$ & {$[0.199]$} & $-0.995^{* *}$ & {$[0.194]$} & $-0.931^{*}$ & {$[0.366]$} & $0.966^{* *}$ & [0.312] & $0.917^{* *}$ & [0.269] & $-0.868^{*} \quad[0.319]$ & $-0.045[1.946]$ & 0.831 \\
\hline South Carolina & $\mid \begin{array}{l}\mid 1.1 \\
1\end{array}$ & $7[0.652]$ & -0.9 & $3[0.702]$ & & {$[0.535]$} & & $6[0.499]$ & & {$[0.376]$} & $-0.948[0.493]$ & -0.398 [2.252] & 0.817 \\
\hline South Dakota & $0.633^{* *}$ & {$[0.137]$} & $-0.586^{* *}$ & [0.135] & $-0.879^{*}$ & {$[0.384]$} & & $5[0.346]$ & $1.089^{*}$ & [0.383] & $-0.733[0.438]$ & $2.509[2.426]$ & 0.804 \\
\hline Tennessee & $1.438^{* *}$ & {$[0.296]$} & $-1.241^{* *}$ & [0.291] & $-1.156^{*}$ & {$[0.268]$} & $1.448^{* *}$ & {$[0.279]$} & $0.689^{*}$ & [0.285] & $\begin{array}{ll}-1.206^{* *} & {[0.318]}\end{array}$ & -2.051 [1.799] & 0.863 \\
\hline Texas & $1.326^{* *}$ & [0.259] & $-1.432^{* *}$ & [0.263] & & {$[0.663]$} & & $8[0.662]$ & & [0.439] & $-0.556[0.560]$ & 1.171 [3.922] & 0.852 \\
\hline Utah & $0.846^{* *}$ & [0.223] & $-0.888^{* *}$ & {$[0.236]$} & & {$[0.424]$} & & $5[0.442]$ & $0.799^{*}$ & [0.351] & $-0.357[0.436]$ & $2.07[2.748]$ & 0.794 \\
\hline Vermont & $1.435^{* *}$ & {$[0.229]$} & $-1.375^{* *}$ & [0.221] & $-1.370^{*}$ & {$[0.328]$} & $1.393^{* *}$ & {$[0.312]$} & $0.821^{* *}$ & {$[0.244]$} & {$\left[\begin{array}{ll}-0.923^{* *} & {[0.290]}\end{array}\right.$} & 0.115 [1.799] & 0.914 \\
\hline Virginia & $0.863^{* *}$ & {$[0.228]$} & $-0.915^{* *}$ & [0.201] & & {$[0.266]$} & $0.808^{* *}$ & [0.211] & $0.386^{*}$ & [0.158] & $-0.859^{* \star}$ & $-3.338^{*} \quad[1.265]$ & 0.924 \\
\hline Washington & $1.033^{* *}$ & {$[0.245]$} & $-1.057^{* *}$ & [0.244] & $-0.828^{*}$ & {$[0.380]$} & $1.080^{*}$ & [0.451] & $0.765^{*}$ & {$[0.319]$} & $-0.993^{*} \quad[0.405]$ & $-1.606[2.605]$ & 0.803 \\
\hline West Virginia & $0.730^{* *}$ & {$[0.239]$} & $-0.666^{*}$ & [0.245] & & {$[0.402]$} & & {$[$ [0.433] } & $0.815^{\star}$ & {$[0.333]$} & $-0.166[0.416]$ & 3.94 [2.346] & 0.668 \\
\hline Wisconsin & 0.6 & {$[0.322]$} & $-0.754^{*}$ & [0.307] & & {$[0.310]$} & & $7[0.412]$ & $0.879^{* *}$ & [0.232] & $-0.957^{* \star} \quad[0.295]$ & $-0.96[1.913]$ & 0.787 \\
\hline Wyoming & $1.469^{* *}$ & {$[0.275]$} & $-1.351^{* *}$ & [0.305] & & {$[1.136]$} & & $+[1.281]$ & 1.4 & [0.991] & $-1.138[1.285]$ & 1.574 [8.347] & 0.768 \\
\hline
\end{tabular}

Standard errors in brackets

All regressions use 26 observations.

${ }^{*}$ significant at $5 \%$; ${ }^{* *}$ significant at $1 \%$ 
Table 2: Mean Absolute Deviations (levels)

\begin{tabular}{|c|c|c|c|}
\hline State & Share Approach & Regression Approach & Difference \\
\hline Alabama & 0.0500 & 0.0089 & 0.0411 \\
\hline Alaska & 0.3242 & 0.0565 & 0.2677 \\
\hline Arizona & 0.0396 & 0.0111 & 0.0285 \\
\hline Arkansas & 0.0472 & 0.0080 & 0.0392 \\
\hline California & 0.0256 & 0.0135 & 0.0121 \\
\hline Colorado & 0.0186 & 0.0081 & 0.0105 \\
\hline Connecticut & 0.0735 & 0.0165 & 0.0570 \\
\hline Delaware & 0.1664 & 0.0206 & 0.1458 \\
\hline District of Columbia & 0.5190 & 0.0170 & 0.5021 \\
\hline Florida & 0.1566 & 0.0056 & 0.1510 \\
\hline Georgia & 0.0368 & 0.0135 & 0.0233 \\
\hline Hawaii & 0.0261 & 0.0140 & 0.0121 \\
\hline Idaho & 0.0475 & 0.0096 & 0.0379 \\
\hline Illinois & 0.0241 & 0.0067 & 0.0173 \\
\hline Indiana & 0.0342 & 0.0112 & 0.0230 \\
\hline lowa & 0.0295 & 0.0081 & 0.0214 \\
\hline Kansas & 0.0404 & 0.0068 & 0.0337 \\
\hline Kentucky & 0.0174 & 0.0133 & 0.0041 \\
\hline Louisiana & 0.1482 & 0.0265 & 0.1217 \\
\hline Maine & 0.1034 & 0.0090 & 0.0944 \\
\hline Maryland & 0.1771 & 0.0085 & 0.1686 \\
\hline Massachusetts & 0.0448 & 0.0056 & 0.0393 \\
\hline Michigan & 0.0648 & 0.0196 & 0.0452 \\
\hline Minnesota & 0.0217 & 0.0052 & 0.0165 \\
\hline Mississippi & 0.0355 & 0.0078 & 0.0277 \\
\hline Missouri & 0.0298 & 0.0161 & 0.0137 \\
\hline Montana & 0.0810 & 0.0179 & 0.0631 \\
\hline Nebraska & 0.0224 & 0.0097 & 0.0127 \\
\hline Nevada & 0.0420 & 0.0054 & 0.0366 \\
\hline New Hampshire & 0.1246 & 0.0145 & 0.1101 \\
\hline New Jersey & 0.0872 & 0.0099 & 0.0773 \\
\hline New Mexico & 0.0781 & 0.0367 & 0.0415 \\
\hline New York & 0.0125 & 0.0068 & 0.0057 \\
\hline North Carolina & 0.0331 & 0.0109 & 0.0222 \\
\hline North Dakota & 0.0548 & 0.0468 & 0.0079 \\
\hline Ohio & 0.0426 & 0.0100 & 0.0326 \\
\hline Oklahoma & 0.0669 & 0.0181 & 0.0489 \\
\hline Oregon & 0.0531 & 0.0150 & 0.0381 \\
\hline Pennsylvania & 0.1030 & 0.0093 & 0.0937 \\
\hline Rhode Island & 0.1106 & 0.0102 & 0.1004 \\
\hline South Carolina & 0.0226 & 0.0110 & 0.0115 \\
\hline South Dakota & 0.0249 & 0.0162 & 0.0088 \\
\hline Tennessee & 0.0091 & 0.0103 & -0.0012 \\
\hline Texas & 0.0821 & 0.0185 & 0.0636 \\
\hline Utah & 0.0284 & 0.0109 & 0.0175 \\
\hline Vermont & 0.0736 & 0.0065 & 0.0670 \\
\hline Virginia & 0.0449 & 0.0086 & 0.0363 \\
\hline Washington & 0.0175 & 0.0111 & 0.0064 \\
\hline West Virginia & 0.0695 & 0.0121 & 0.0573 \\
\hline Wisconsin & 0.0438 & 0.0068 & 0.0370 \\
\hline Wyoming & 0.2204 & 0.0352 & 0.1852 \\
\hline average & 0.0732 & 0.0140 & \\
\hline $\min$ & 0.0091 & 0.0052 & \\
\hline $\max$ & 0.5190 & 0.0565 & \\
\hline median & 0.0449 & 0.0109 & \\
\hline
\end{tabular}


Table 3: Mean Absolute Deviations (growth rates)

\begin{tabular}{|c|c|c|c|}
\hline State & Share Approach & Regression Approach & Difference \\
\hline Alabama & 0.0097 & 0.0091 & 0.0006 \\
\hline Alaska & 0.0994 & 0.0718 & 0.0276 \\
\hline Arizona & 0.0128 & 0.0123 & 0.0005 \\
\hline Arkansas & 0.0094 & 0.0083 & 0.0011 \\
\hline California & 0.0151 & 0.0138 & 0.0013 \\
\hline Colorado & 0.0106 & 0.0091 & 0.0014 \\
\hline Connecticut & 0.0139 & 0.0120 & 0.0020 \\
\hline Delaware & 0.0222 & 0.0178 & 0.0044 \\
\hline District of Columbia & 0.0141 & 0.0104 & 0.0037 \\
\hline Florida & 0.0091 & 0.0057 & 0.0034 \\
\hline Georgia & 0.0093 & 0.0077 & 0.0016 \\
\hline Hawaii & 0.0124 & 0.0096 & 0.0027 \\
\hline Idaho & 0.0140 & 0.0123 & 0.0018 \\
\hline Illinois & 0.0070 & 0.0068 & 0.0002 \\
\hline Indiana & 0.0101 & 0.0096 & 0.0006 \\
\hline lowa & 0.0109 & 0.0076 & 0.0034 \\
\hline Kansas & 0.0063 & 0.0054 & 0.0010 \\
\hline Kentucky & 0.0133 & 0.0131 & 0.0002 \\
\hline Louisiana & 0.0384 & 0.0310 & 0.0074 \\
\hline Maine & 0.0100 & 0.0078 & 0.0021 \\
\hline Maryland & 0.0083 & 0.0064 & 0.0019 \\
\hline Massachusetts & 0.0082 & 0.0049 & 0.0033 \\
\hline Michigan & 0.0170 & 0.0154 & 0.0016 \\
\hline Minnesota & 0.0094 & 0.0084 & 0.0010 \\
\hline Mississippi & 0.0094 & 0.0085 & 0.0009 \\
\hline Missouri & 0.0134 & 0.0116 & 0.0017 \\
\hline Montana & 0.0169 & 0.0126 & 0.0042 \\
\hline Nebraska & 0.0148 & 0.0109 & 0.0039 \\
\hline Nevada & 0.0057 & 0.0048 & 0.0008 \\
\hline New Hampshire & 0.0170 & 0.0148 & 0.0021 \\
\hline New Jersey & 0.0122 & 0.0088 & 0.0034 \\
\hline New Mexico & 0.0344 & 0.0342 & 0.0001 \\
\hline New York & 0.0082 & 0.0082 & 0.0000 \\
\hline North Carolina & 0.0102 & 0.0089 & 0.0013 \\
\hline North Dakota & 0.0316 & 0.0233 & 0.0083 \\
\hline Ohio & 0.0095 & 0.0086 & 0.0009 \\
\hline Oklahoma & 0.0197 & 0.0193 & 0.0003 \\
\hline Oregon & 0.0140 & 0.0131 & 0.0008 \\
\hline Pennsylvania & 0.0094 & 0.0087 & 0.0007 \\
\hline Rhode Island & 0.0107 & 0.0103 & 0.0004 \\
\hline South Carolina & 0.0114 & 0.0111 & 0.0002 \\
\hline South Dakota & 0.0185 & 0.0138 & 0.0048 \\
\hline Tennessee & 0.0092 & 0.0082 & 0.0010 \\
\hline Texas & 0.0172 & 0.0141 & 0.0031 \\
\hline Utah & 0.0150 & 0.0131 & 0.0020 \\
\hline Vermont & 0.0112 & 0.0092 & 0.0020 \\
\hline Virginia & 0.0089 & 0.0061 & 0.0028 \\
\hline Washington & 0.0109 & 0.0110 & -0.0001 \\
\hline West Virginia & 0.0146 & 0.0118 & 0.0029 \\
\hline Wisconsin & 0.0081 & 0.0077 & 0.0005 \\
\hline Wyoming & 0.0408 & 0.0345 & 0.0063 \\
\hline average & 0.0156 & 0.0130 & \\
\hline $\min$ & 0.0057 & 0.0048 & \\
\hline $\max$ & 0.0994 & 0.0718 & \\
\hline median & 0.0114 & 0.0103 & \\
\hline
\end{tabular}




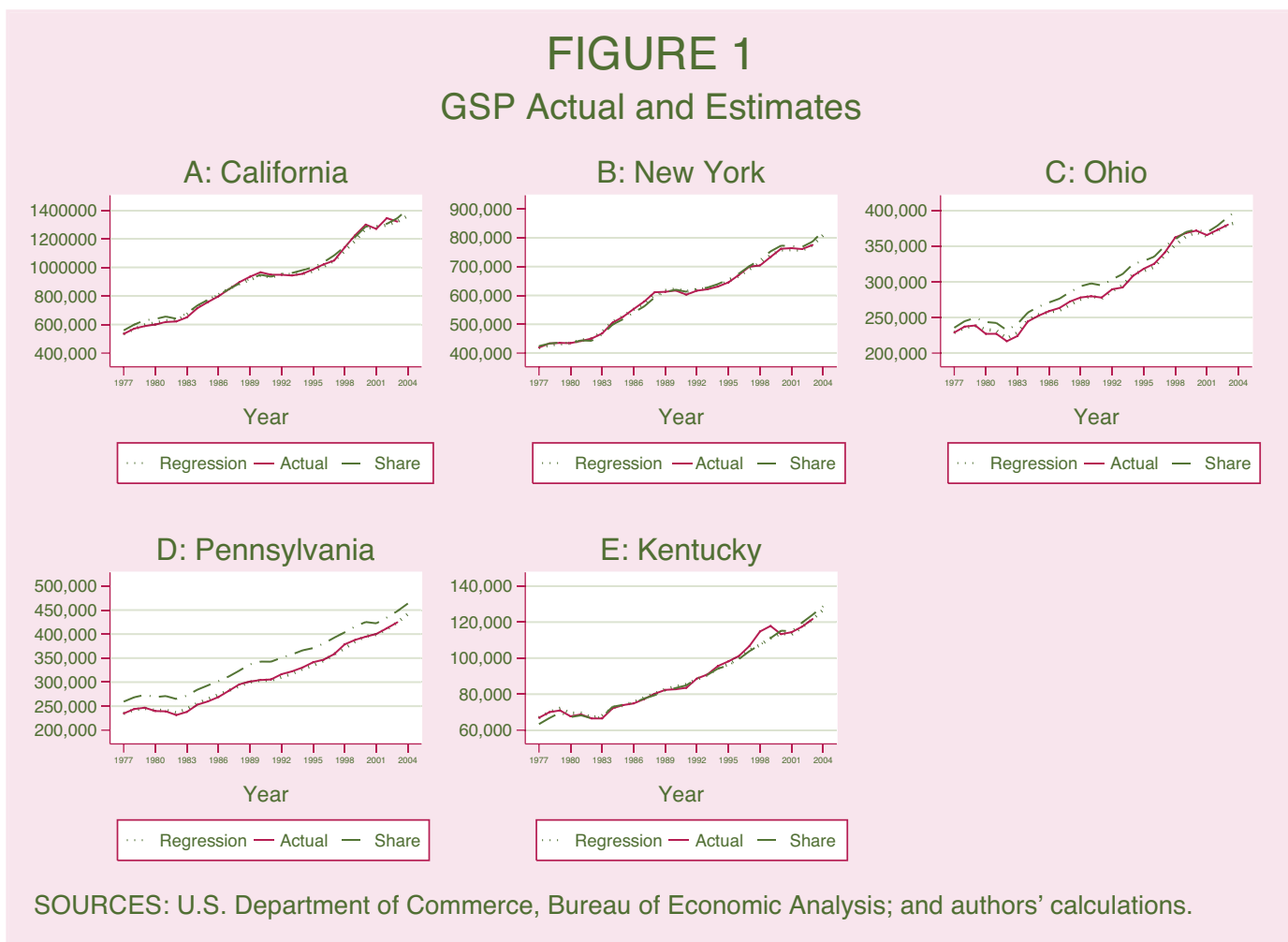

FIGURE 2

Changes in Real GSP and GSP Estimates

A: California

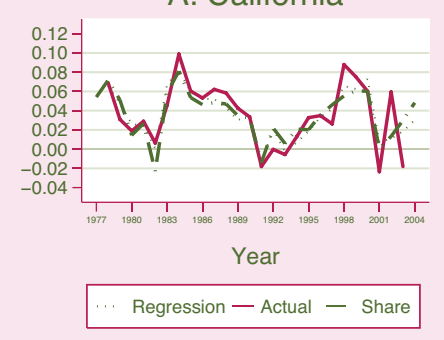

D: Pennsylvania

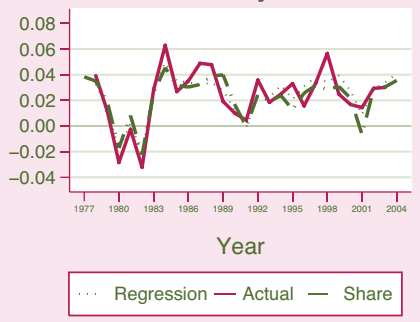

B: New York

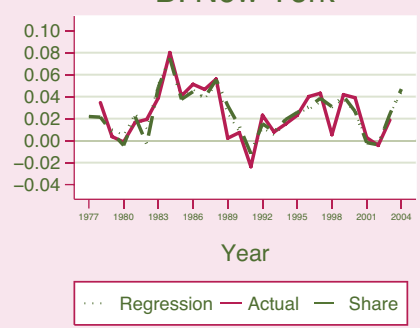

E: Kentucky

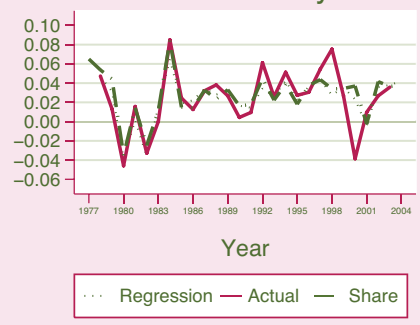

SOURCES: U.S. Department of Commerce, Bureau of Economic Analysis; and authors' calculations. 


\section{FIGURE 3}

\section{GSP Actual and Estimates}

\section{A: Alaska}

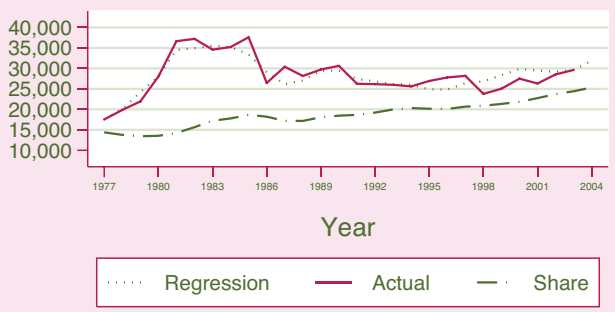

C: Louisiana

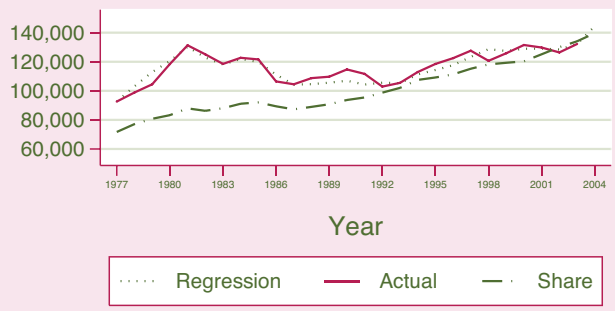

B: Texas

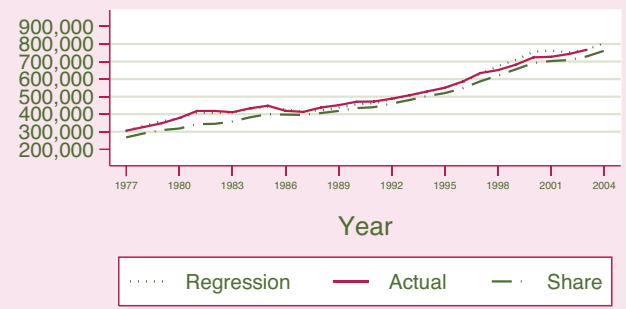

D: West Virginia

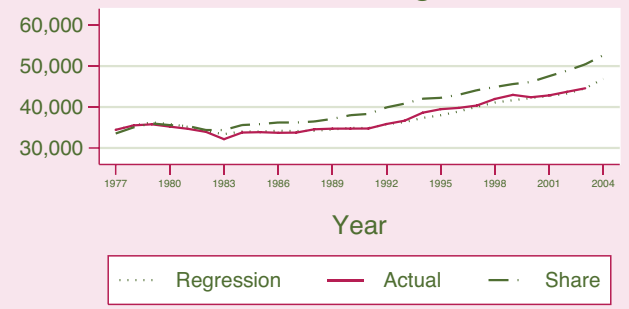

SOURCES: U.S. Department of Commerce, Bureau of Economic Analysis; and authors' calculations.

FIGURE 4 Changes in Real GSP and GSP Estimates

A: Alaska

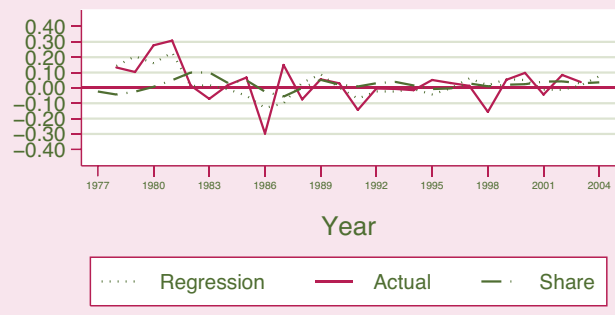

C: Louisiana

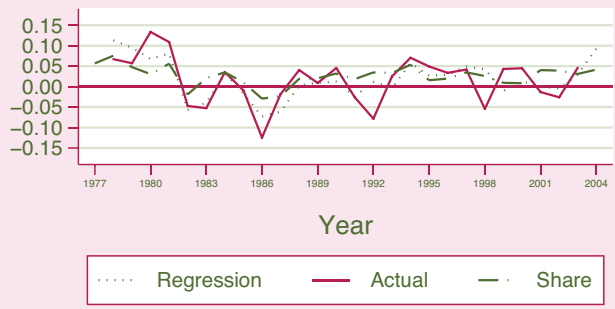

B: Texas

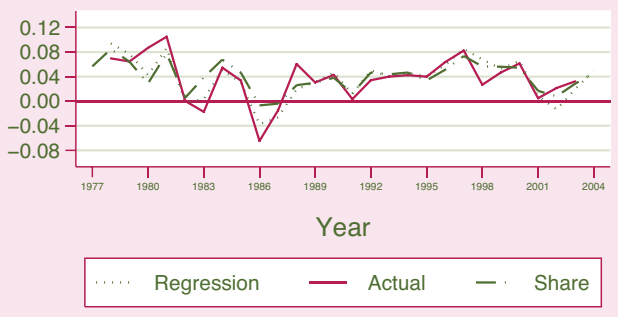

D: West Virginia

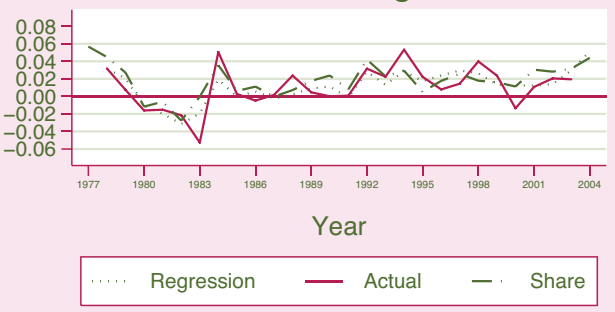

SOURCES: U.S. Department of Commerce, Bureau of Economic Analysis; and authors' calculations. 


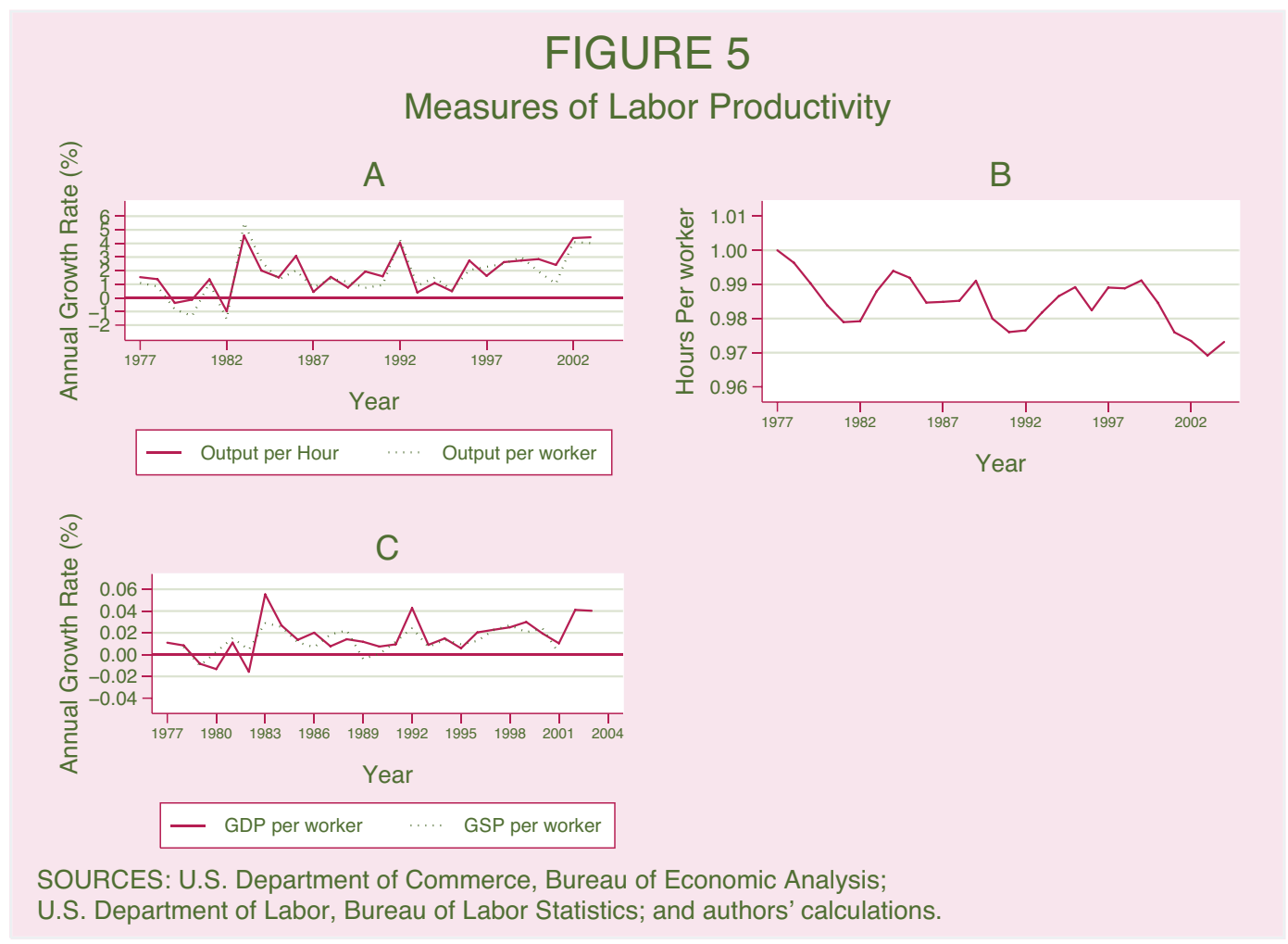



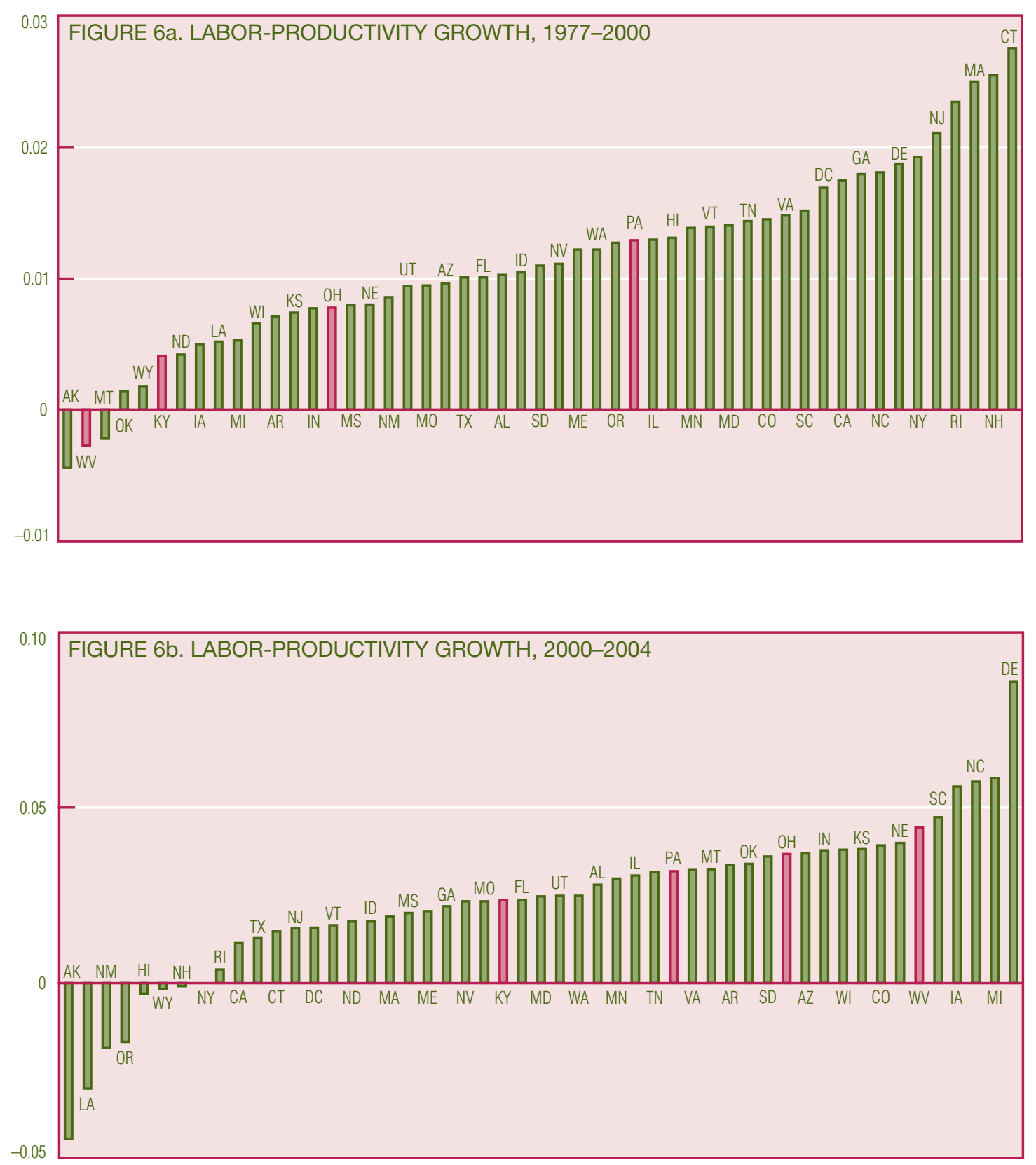

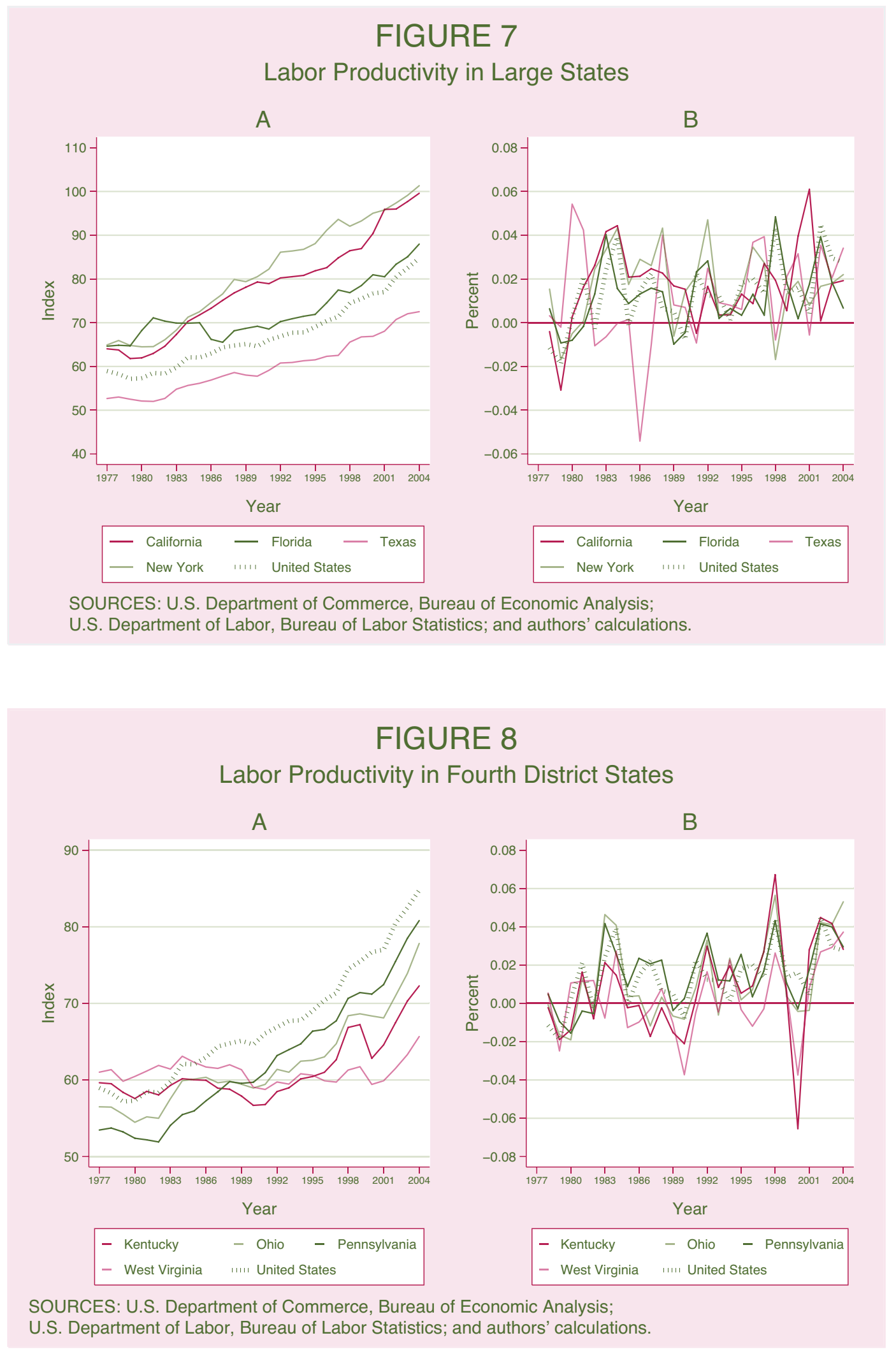
POLICY DISCUSSION PAPERS NUMBER 16, MARCH 2006

Notes 


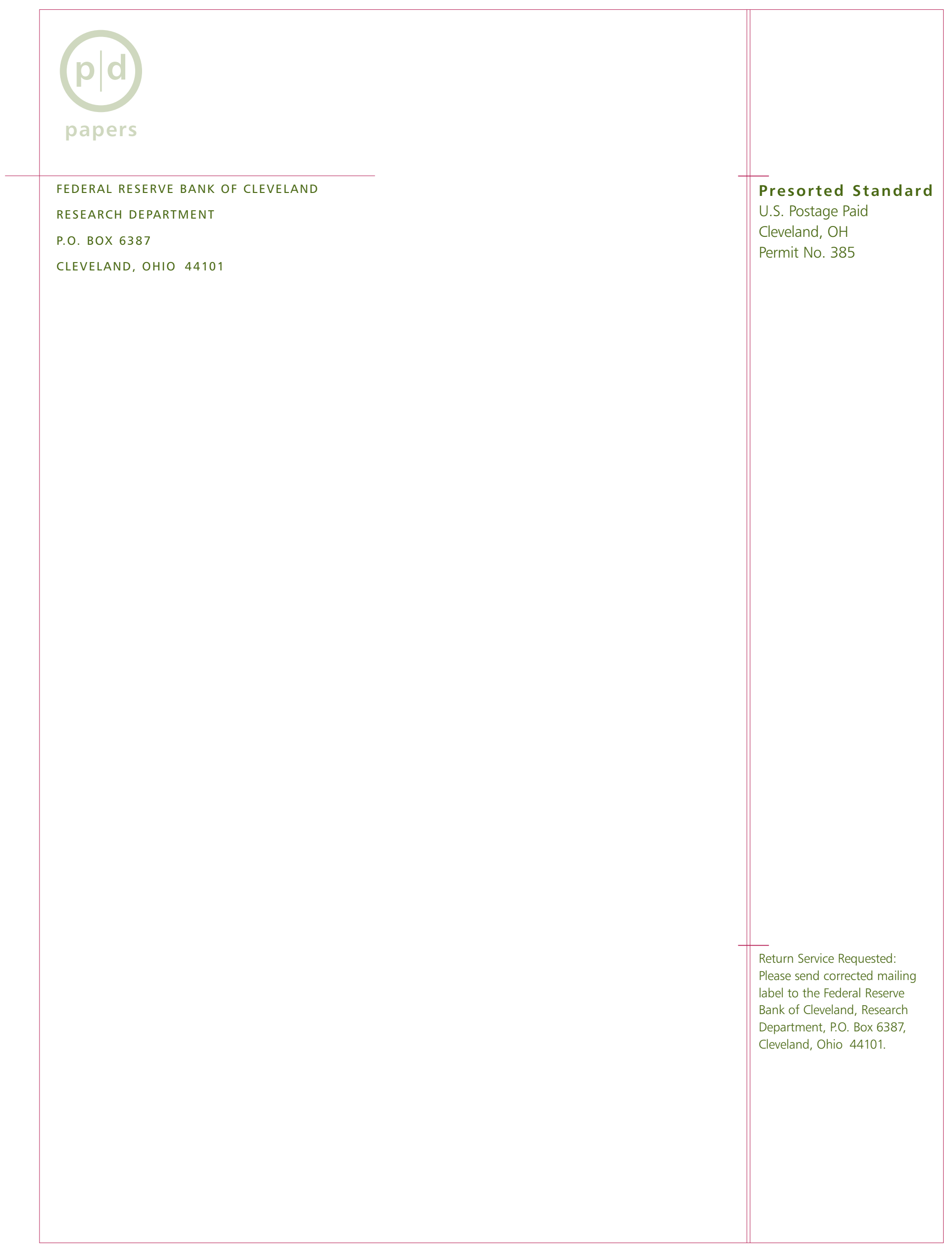

